DOI : $10.14746 /$ rie.2019.13.29

\title{
Marta Ryniejska-Kiełdanowicz, Dyplomacja publiczna Unii Europejskiej, Wydawnictwo Naukowe Scholar, Warszawa 2019, ss. 292.
}

Przedmiotem oceny jest monografia pt. Dyplomacja publiczna Unii Europejskiej autorstwa Marty Ryniejskiej-Kiełdanowicz, opublikowana przez Wydawnictwo Naukowe Scholar, Warszawa 2019, składająca się z pięciu rozdziałów opatrzonych wstępem, zakończeniem oraz bibliografią, o łącznej objętości ponad 290 stron.

Recenzowana książka jest przygotowana z właściwym kunsztem badawczym. W pierwszych dwóch rozdziałach Autorka wskazała zasadność doboru metod i teorii zastosowanych do analizy w dalszych częściach pracy. W prezentowanej monografii Autorka dokonuje ocen oraz definiuje obszary działalności Unii Europejskiej przy użyciu nowego spojrzenia naukowego, co powoduje, że oceniana książka, z jednej strony, jest ze wszech miar innowacyjna, a z drugiej, pozostaje aplikacyjnym wzorcem prac naukowych. Sumując powyższe rozważania oceniania publikacja porusza aktualne zagadnienie, prezentowane zarówno w ujęciu naukowym, dydaktycznym, jak i popularyzującym wiedzę. Monografia jest wciągającą lekturą napisaną w taki sposób, aby każdy czytelnik mógł zapoznać się z omawianymi zagadnieniami.

We wstępie recenzowanej monografii Autorka dokonała przeglądu stanu badań w dziedzinie dyplomacji unijnej. Wśród istotnych Autorka wskazała rozbieżności wynikające z podejść badawczych w zależności od dyscypliny naukowej reprezentowanej przez autora oraz stosowanych metod i podejść naukowych do badania i definiowania dyplomacji publicznej UE. W odróżnieniu od automatycznego skojarzenia z pojęciem dyplomacji uprawianej przez państwa w kierunku na zewnątrz Autorka recenzowanej monografii proponuje badać także działania skierowane do wewnątrz systemu - określane jako metoda zarządzania pluralizmem (zgodnie z mottem UE). Bowiem Europejczycy powinni działać wspólnie by chronić pokój, dobrobyt i bogactwo kultur. Niestety często rozbieżności interesów między państwami członkowskimi prowadzą do chęci realizacji różnych strategii dyplomacji, często określanych mianem modeli integracyjnych, np. à la carte, federacyjnym czy imperialnym.

Konstrukcja pracy wskazuje, że jest realizacją przemyślanego zamysłu badawczego Autorki. Zwłaszcza podział pracy na część teoretyczną i weryfikację empiryczną podnosi walor publikacji do rangi wysoko ocenianych monografii naukowych prezentujących bardzo dobry warsztat naukowy, który powinien być upowszechniany w celach dydaktycznych dla kolejnych pokoleń naukowców. W części teoretycznej praca dodatkowo nie jest wyłącznie opisem, ewentualnie zbiorem definicji, lecz jest celowym zamysłem, jest projekcją autorską, jest innowacyjnym elementem, jest uzupełnieniem stanu badań w tej dziedzinie o nowe wartości, o nowe definicje, jest elementem twórczym a nie odtwórczym. Podobnie jest z zastosowaniem warsztatu dla uporządkowania wiedzy, co jest niezbędnym walorem każdego badania, stawianym na pozycji ważnego problemu badawczego, by uporządkować przedmiot badania. Wszystkie te czynności prezentowane w pierwszej części monografii stanowią o wartości i celowości ocenianej monografii, stanowią o jej innowacyjnym charakterze i jednocześnie o jej walorze poznawczym.

Z tego powodu recenzowana monografia wyróżnia się na rynku i stanowi inspirujące opracowanie o szerokich walorach poznawczych, integrujących podejścia badawcze, sama Autorka sugeruje, że jest to pozycja interdyscyplinarna. Analiza prowadzona jest na kilku płaszczyznach oraz jest otwarta na różne środowiska odbiorców. Czytelnikiem tej publikacji mogą być 
zarówno urzędnicy - fachowe kadry pracowników różnych sektorów administracji publicznej, politycy i parlamentarzyści, a także przedstawiciele środowiska akademickiego (naukowcy, eksperci oraz studenci). W gronie czytelników należy spodziewać się osób zainteresowanych problematyką konstrukcji i funkcjonowania zarówno współczesnego państwa, a także stricte środowiska międzynarodowego, w tym zwłaszcza organizacji międzynarodowych takich jak Unia Europejska.

Sumując należy podkreślić, że Autorka ocenianej monografii wykazała się erudycją, tak w warstwie faktograficznej, jak i teoretycznej, dowodząc bardzo dobrego rozeznania w podjętej przez siebie problematyce. Lektura publikacji potwierdza umiejętność dowodzenia własnych racji, jak i prowadzenia polemiki z poglądami innych autorów. Wywód jest precyzyjny i logiczny, co umożliwia prawidłowa konstrukcja publikacji. Podjęty przez Autorkę temat jest ważny, tak w płaszczyźnie teoretycznej, jak i poznawczej. Ważną konstatacją jest stwierdzenie, że znaczenie problematyki międzynarodowego wymiaru integracji europejskiej jest w literaturze niedoceniane. Prezentowana monografia ma szanse stanowić istotny wkład do badań w tym zakresie.

MARTA WITKOWSKA

Uniwersytet Warszawski 